\title{
Effect of Particle Size and Quality of Pruning Wood Residues of Asian Pear (Pyrus pyrifolia and Pyrus communis) On C-And N-Mineralisation in Soils of Contrasting Textures ${ }^{1}$
}

\author{
F.J. Matus ${ }^{2,3}$, J.B. Retamales ${ }^{2}$, P. Sánchez ${ }^{2}$ \\ ${ }^{2}$ Facultad de Ciencias Agrarias, Universidad de Talca, Casilla 747, Talca-Chile \\ ${ }^{3}$ Current adress: Departamento de Ciencias Químicas, Universidad de la Frontera. \\ Correspondence: matus.francisco@gmail.com
}

\section{Efecto del tamaño de partícula y calidad de la madera de residuos de poda de peras asiáticas sobre la mineralización de $\mathrm{C}$ y $\mathrm{N}$ en suelos con distinta textura}

Key words: Residue particle size, pear pruning residues, $\mathrm{C}$ and $\mathrm{N}$ mineralisation rates.

\begin{abstract}
A laboratory incubation study $\left(22^{\circ} \mathrm{C} \pm 2{ }^{\circ} \mathrm{C}\right)$ with pruning residues of Asian pear $(P$. pyrifolia, cv. Hosui) was carried out to determine the effects of residue particle size $(<0.5$ $\mathrm{mm}, 0.5-2 \mathrm{~mm}$ and 2-4 mm), residue quality (defined as C-to-N ratio, and total fibre content of each size class) and soil texture on $\mathrm{C}$ - and $\mathrm{N}$-mineralisation in two Chilean soils. Particle size had a significat impact on $\mathrm{C}$-mineralisation; however, no differences were observed for $\mathrm{N}$-mineralisation. After 10 days of incubation, particles $<0.5 \mathrm{~mm}$ evolved more $\mathrm{C}-\mathrm{CO}_{2}$ than medium $(0.5-2 \mathrm{~mm})$ and coarse particles. Thereafter, no significant $(\mathrm{P}<0.05)$ differences were observed for the smaller particles, while coarse sizes showed low $\mathrm{C}-\mathrm{CO}_{2}$ evolution during the all incubation period, except at the last sampling where $\mathrm{C}-\mathrm{CO}_{2}$ tended to be similar than $<0.5$ and $2-4 \mathrm{~mm}$ particles. The higher $\mathrm{C}-\mathrm{CO}_{2}$ evolved from the smallest particles coincided with their low $\mathrm{C}$-to-N ratio and low fibre content. There was no effect of soil texture on $\mathrm{C}$ and $\mathrm{N}$-mineralisation. These results were explained on the basis of residue quality rather than soil type.
\end{abstract}

Palabras claves: Tamaño de particular de los residuos, residuos de poda de peráles, tasas de mineralización de $\mathrm{C}$ y N

${ }^{1}$ Parte de este trabajo fue presentado al VI ${ }^{\text {Ith }}$ International Symposium on Pear Growing. Acta Horticulturae (1997), 475: 327-337. 


\section{RESUMEN}

Un estudio de incubación en laboratorio $\left(22^{\circ} \mathrm{C} \pm 2{ }^{\circ} \mathrm{C}\right)$ con residuos de poda de pera asiática (P. pyrifolia, cv. Hosui) fue conducido para determinar el efecto del tamaño de partículas $(<0,5 \mathrm{~mm}, 0,5-2 \mathrm{~mm}$ and 2-4 $\mathrm{mm}$ ), calidad de la madera (definida por su relación $\mathrm{C}: \mathrm{N}$ y contenido de fibra total en cada tamaño) y textura del suelo sobre la mineralización de $\mathrm{C}$ y $\mathrm{N}$ en dos suelos chilenos. El tamaño de partícula tuvo un impacto significativo sobre la mineralización de $\mathrm{C}$; sin embargo, no hubo diferencias para la mineralización de N. Después de 10 días de incubación, las partículas $<0.5 \mathrm{~mm}$ liberaron más $\mathrm{C}-\mathrm{CO}_{2}$ que las de tamaño mediano $(0,5-2 \mathrm{~mm})$ y grueso. Después, no hubo diferencias significativas $(\mathrm{P}<0,05)$ para las partículas pequeñas, mientras que las de tamaño grueso presentaron baja liberación de $\mathrm{C}-\mathrm{CO}_{2}$ durante todo el período de incubación, excepto en el último muestreo donde el $\mathrm{C}-\mathrm{CO}_{2}$ tendió a ser similar que las partículas $<0,5$ y 2-4 mm. La mayor liberación de C- $\mathrm{CO}_{2}$ desde las partículas pequeñas coincidió con su baja relación $\mathrm{C}$ : $\mathrm{N}$ y su bajo contenido de fibra. No hubo efecto de la textura del suelo sobre la mineralización de $\mathrm{C}$ y N. Estos resultados fueron explicados sobre la base de la calidad del residuo más que por el tipo de suelo.

\section{INTRODUCTION}

In Chile, pear pruning wood residues are often reincorporated into the soil, in order to ameliorate nutrient losses associated with fruit harvesting. Although prunings are usually chopped to promote decomposition, to the best of our knowledge, the impact of residue particle size on decomposition rates has not been studied quantitatively for fruit tree species. In a broader context, controversy still exists regarding the effect of particle size on decomposition. Waksman (1952) and Russell (1961) were perhaps the first to forward the idea that the higher surface/mass ratios of small particles would favour microbial action. However, Sims and Frederick (1970) demonstrated that the decomposition is greater in the coarse than in the fine particles and demonstrated that clay minerals may inhibit $\mathrm{N}$-mineralisation during the first stage of decomposition; this was attributed to a higher protection by clay minerals on microbial biomass and metabolites formed during initial decomposition (Jensen, 1994). On the other hand, decomposition of crop residues may be influenced by residue quality. A number of papers have considered the importance of residue quality on $\mathrm{C}$ - and $\mathrm{N}$-mineralisation (Vanlauwe,1996; Kachaka et al., 1993; Tian et al., 1992; Oglesby and Fownes, 1992; Palm and Sánchez, 1991). Decomposition is inhibited in low quality residues, because of their high lignin or polyphenols content or high C-to-N ratio. A caveat is appropriate at this point, since Vanlauwe (1996) demonstrated that the effect of residue particle size on the efficiency of chemical extraction in fibre analysis may lead to spurious conclusions.

The objective of this paper is to study the $\mathrm{C}$ - and $\mathrm{N}$-mineralisation of pruning residues from Asian pear cultivars Hosui (Pyrus pyrifolia and Pyrus Communis) as influenced by their particle sizes and quality in two soils of contrasting textures. 


\section{MATERIALS AND METHODS}

\section{Incubation experiments}

Wood residues were collected two months after pruning. All materials were washed with tap water, dried at $70^{\circ} \mathrm{C}$ for five days, milled (knife mill) and hand sieved to obtain three particle size classes: $<0.5,0.5$ 2 and 2-4 $\mathrm{mm}$. Residues were analyzed for total fibre content by Neutral Detergent Fibre (NDF) (Van Soest and Wine, 1967), Acid Detergent Fibre (ADF) (Van Soest and Wine, 1968) and lignin content using 72\% $\mathrm{H}_{2} \mathrm{SO}_{4}$ (Van Soest, 1963). Organic-C was analysed by dichromate complete oxidation (Matus, 1994) and total-N by Kjeldahl method. Incubations were conducted with two soils: Wapri-loamy soil (clay $=28.5 \%$, $\mathrm{C}=2.9 \%, \mathrm{~N}=0.3 \%$ ) under 5-year-old pear trees and Hualañé-sandy soil (clay $=11.9 \%$, $\mathrm{C}=0.55 \%, \mathrm{~N}=0.003 \%$ ) which had long term cultivation with cereals. The effect of particles size on $\mathrm{C}$-and $\mathrm{N}$-mineralisation were essayed in Wapri soil and the effect of soil texture on $\mathrm{C}$ and $\mathrm{N}$-mineralization were only examined on particles of $0.5-2 \mathrm{~mm}$.

Potential C-mineralisation was assayed by mixing $50 \mathrm{~g}$ of soil (dry weight basis), sieved through $0.005 \mathrm{~m}$ mesh size, with $100 \mathrm{mg}$ of wood materials and moistened to a water potential of $-33 \mathrm{kPa}$. Three replicates of each sample were incubated. The soil and residue samples were placed in a 2 litre airtight glass jar containing a vial with $10 \mathrm{ml}$ of $0.5 \mathrm{M}$ $\mathrm{NaOH}$ and incubated at $22{ }^{\circ} \mathrm{C}\left( \pm 2{ }^{\circ} \mathrm{C}\right)$ in darkness during 3, 10, 15, 30 and 60 days. At each sampling time, trapped $\mathrm{C}-\mathrm{CO}_{2}$ was precipitated as carbonate with excess 0.75 $\mathrm{MBaCl}_{2}$ and excess $\mathrm{NaOH}$ was titrated with $0.5 \mathrm{M} \mathrm{HCl}$ to reach $\mathrm{pH} 8.3$ (Dalal, 1979). At each sampling time, a new vial containing $\mathrm{NaOH}$ was placed into the glass jar. Although the decomposition rate is normally described by a first order kinetic, the rate of carbon mineralisation were calculated as the difference of $\mathrm{C}-\mathrm{CO}_{2}$ evolved between two sampling times, divided by the length of the incubation period. Potential N-mineralisation was essayed following the same procedure as for the C-mineralisation, but $100 \mathrm{~g}$ of soil were mixed with $200 \mathrm{mg}$ of wood residues. Incubation was carried out in $0.3 \mathrm{~L}$ flasks provided with a perforated lit to allow gas exchange. The moisture content was adjusted weekly with demineralised water. Mineral-N (N-NH4 ${ }^{+}$and N-NO3-) was extracted after 10, 30 and 90 days of incubation with $2 \mathrm{M} \mathrm{KCl}$ solution at soil:solution ratio 1:10. Mineral-N was measured by Kjeldahl method with $\mathrm{MgO}$ and Devarda's alloy. As for C-mineralisation, the $\mathrm{N}$-mineralisation rate was calculated as the difference of $\mathrm{N}$-mineralised between two sampling dates, divided by the time elapsed.

\section{Statistical design and analysis}

A completely randomized block design was used. Statistical effects of particle size, cultivars and soils type was computed in JMP (SAS Institute, Cary, NC, U.S.A.). Analysis of variance (ANOVA; Statgraphic, 5), and Student's t-test were applied to analyse the differences of means amongst treatments. The probability at which significant differences were compared was set at $5 \%$ level.

\section{RESULTS AND DISCISSION}

All residue particle size classes presented statistically similar $\mathrm{C}$ content, ranging from $42 \%$ to $44 \%$ (Table 1 ). Nitrogen varied between $0.66 \%$ and $1.08 \%$ with highest values for the $<0.5 \mathrm{~mm}$ particles; therefore, this fraction presented the lowest C-to-N ratio. Total fibre content, determined by NDF and ADF, was always lower for $<0.5 \mathrm{~mm}$ particles; however, $<0.5$ $\mathrm{mm}$ and $0.5-2 \mathrm{~mm}$ fractions showed the highest lignin content. 


\section{Table 1}

Characteristics of various particle size classes from Asian pear pruning wood residues (Hosui cultivar)

Cuadro 1. Característica del residuo de poda de peras asiáticas (cultivar Hosui)

\begin{tabular}{lrcr}
\hline \multirow{2}{*}{$\begin{array}{l}\text { Chemical } \\
\text { composition }\end{array}$} & \multicolumn{4}{c}{ Particle size classes (mm) } \\
\cline { 2 - 5 } & $<0.5$ & $0.5-2$ & $2-4$ \\
\hline C (\%) & $43.1 \mathrm{a}$ & $44.0 \mathrm{a}$ & $42.2 \mathrm{a}$ \\
N (\%) & $1.1 \mathrm{a}$ & $0.7 \mathrm{~b}$ & $0.7 \mathrm{~b}$ \\
C-to-N ratio & $39.8 \mathrm{~b}$ & $63.5 \mathrm{a}$ & $63.4 \mathrm{a}$ \\
NDF (\%) & $59.0 \mathrm{~b}$ & $77.0 \mathrm{a}$ & $76.5 \mathrm{a}$ \\
ADF (\%) & $43.7 \mathrm{c}$ & $51.4 \mathrm{a}$ & $47.2 \mathrm{~b}$ \\
Lignin (\%) & $14.0 \mathrm{a}$ & $12.1 \mathrm{ab}$ & $11.3 \mathrm{~b}$
\end{tabular}

Values followed by different letter within a row, are significantly different at $5 \%$ level.

$\mathrm{NDF}=$ Neutral detergent fiber (Van Soest and Wine, 1967).

$\mathrm{ADF}=$ Acid detergent fiber $($ Van Soest and Wine, 1968)

$\mathrm{C}-\mathrm{CO}_{2}$ evolution from all residues and soil doubled the amount produced by the control (Fig. 1). After 3 days of incubation, more $\mathrm{C}-\mathrm{CO}_{2}$ had evolved from the smallest fraction than medium size $(0.5-2 \mathrm{~mm})$ and coarse size (2-4 mm) fraction. Medium size particles produced as much $\mathrm{C}-\mathrm{CO}_{2}$ as the coarse fractions during the first 10 days of incubation. Thereafter, $\mathrm{C}-\mathrm{CO}_{2}$ evolution from both $<0.5$ and $0.5-2 \mathrm{~mm}$ particles was higher than that from the $2-4 \mathrm{~mm}$ particles, except at the last sampling time where the $\mathrm{C}-\mathrm{CO}_{2}$ from $<0.5 \mathrm{~mm}$ particles was similar than that from 2-4 mm .

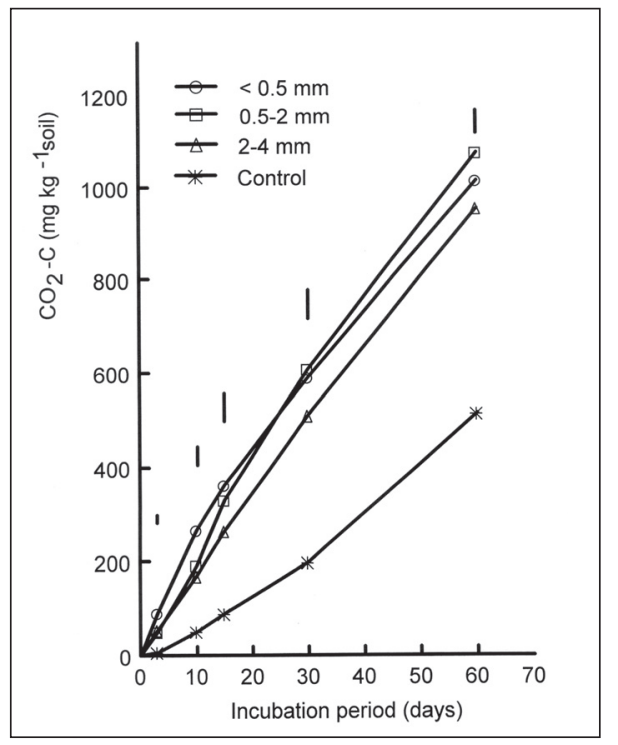

Figure 1. C- $\mathrm{CO}_{2}$ evolution from Asian pear pruning residues (Pyrus pyriforia, cv. Hosui) of various particle size classes. Error bars indicate LSD $(5 \%)$ for comparing treatments with residue additions at the same level of time.

Figura $1 \mathrm{C}-\mathrm{CO}_{2}$ mineralización de residuos de poda de peras asiatiocas (Pyrus pyriforia, cv. Hosui) de varios clases de tamaños de partículas. La barra indica la diferencia mínimina significativa (LSD, $5 \%)$ para comprar tratamientos con la adición de residuos en el mismo tiempo de muestreo. 
No significant differences were observed for N-mineralisation (Fig. 2). After 10 days of incubation, particles between 0.5 $2 \mathrm{~mm}$ and $2-4 \mathrm{~mm}$ tended to mineralise more, while fine particles $(<0.5 \mathrm{~mm})$ tended to show net immobilisation. By day 30, all residues exhibited net immobilisation, but at the last sampling, most particles tended to mineralise more than the control.

The C-CO $\mathrm{CO}_{2}$ evolution of particles 0.5-2 mm was higher in Wapri than in Hualañé soil (Fig. 3). Wapri soil had a much higher $\mathrm{C}$ content $(2.9 \%)$ than Hualañé soil $(0.55 \%)$. There were no significant differences for Cmineralization rates between soils (Table 2). Very similar results were observed for $\mathrm{N}$ mineralisation (Fig. 4). During the first 10 days of incubation, Hualañé soils showed a high significant $(\mathrm{P}<0.05)$ net $\mathrm{N}$ inmobilisation, while Wapri soils showed a net $\mathrm{N}$-mineralisation. Between 10 and 30 days of incubation, both soils showed a net inmobilisation but Wapri soils had the highest rate of $\mathrm{N}$-inmobilisation. Thereafter, both soils showed a net $\mathrm{N}$-mineralisation and no significant differences were observed.

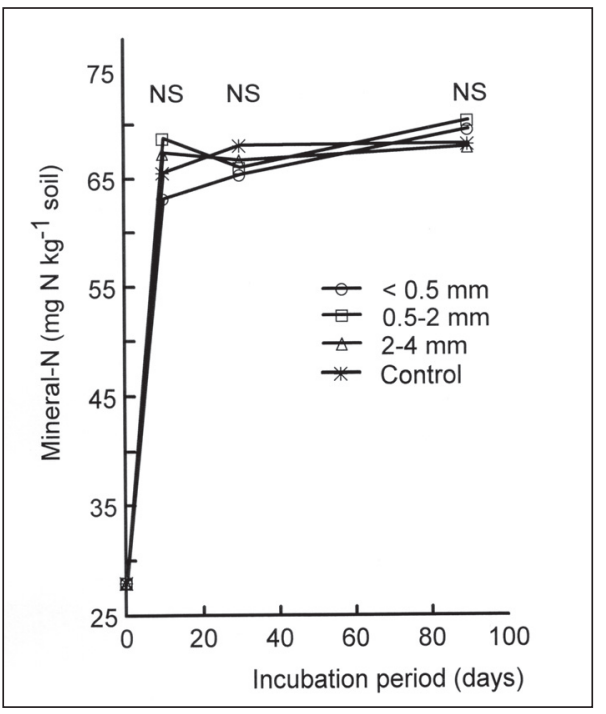

Figure 2. Mineral-N release of pear pruning residues (Pyrus pyriforia) of various particles size classes. NS means 'not significant' $(5 \%)$ for comparing treatments with residue additions at the same level of time.

Figura 2. mineralización de residuos de poda de peras asiatiocas (Pyrus pyriforia, cv. Hosui) de varios clases de tamaños de partículas. NS significa que no hubo 'diferencias' al nivel ( $5 \%$ para comprar tratamientos con la adición de residuos en el mismo tiempo de muestreo.

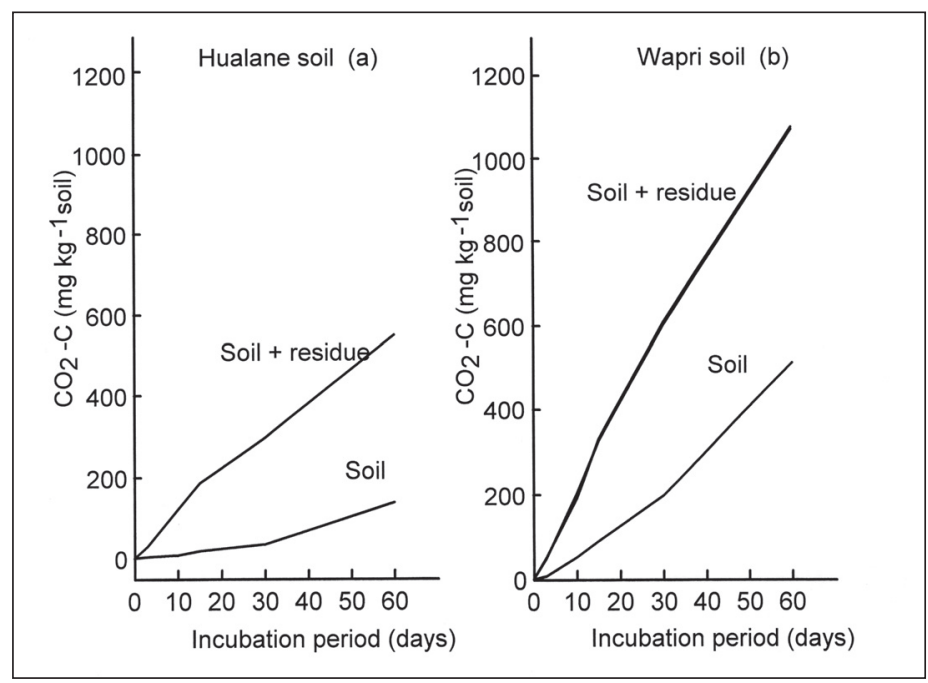

Figure. 3. $\mathrm{C}-\mathrm{CO}_{2}$ evolution from pear pruning residues of $0.5-2 \mathrm{~mm}$ in (a) Hualañé sandy soil and (b) Wapri loamy soil.

Figura 3. C-CO mineralización de residuos de poda de 0,5-2 mm en: (a) suelo Hualañé, franco arenoso y (b) suelo Wapri, franco. 


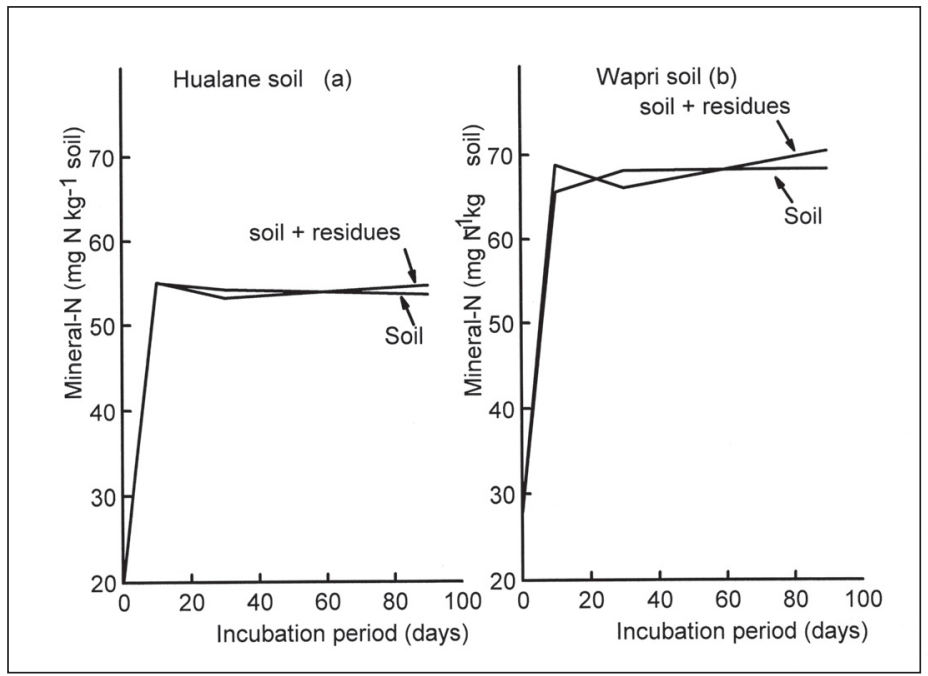

Figure. 4. Mineral-N release from pear pruning residues of 0.5-2 $\mathrm{mm}$ in (a) Hualañé sandy soil and (b) Wapri loamy soil.

Figura 4. Mienralización de $\mathrm{N}$ de residuos de poda de 0,5-2 mm en: (a) suelo Hualañé, franco arenoso y (b) suelo Wapri, franco.

These results show that the some chemical characteristics of the wood residue such as C-to-N ratio and total fibre content (ADF and NDF) were lower in the smallest particles $(<0.5 \mathrm{~mm})$. This is consistent with the report from Vanlauwe (1996), who worked with agroforestry leaves $(\underline{L}$. leucocephala, S. siamea, G. sepium, $\underline{F}$. macrophylla and D. barteri) and showed that residue particle size had a substantial impact on its quality characteristics; thus, smaller particles resulted in higher cold and hot water-soluble fractions, lower fibre contents and higher polyphenol contents (Table 1). They also demonstrated the occurrence of a methodological artifact since smaller particles led to a more exhaustive extraction of plant components because of their larger contact surface. We intended to verify Vanlauwe's conclusion by further grinding particles of 2-4 $\mathrm{mm}$ and $0.5-2 \mathrm{~mm}$ to $<1 \mathrm{~mm}$ particles in order to compare their chemical characteristics. Unfortunately, fibre analysis were performed for particles 0.5-2 $\mathrm{mm}$ only. Although the distribution of $<1$ $\mathrm{mm}$ particles in $0.5-2 \mathrm{~mm}$ were not measured before grindings, total fibre contents of the ground fractions were very similar to $0.5-2$ mm particles (data not shown). This may emphasise the need study in detail the effect of the type (ball or knife mill) and duration of milling on chemical characteristics of wood residues after physical fractionation (Vanlauwe, 1996) and how it affects the intrinsic wood hardness within the plants.

As in most of studies, in this report, the differences between $\mathrm{C}-\mathrm{CO}_{2}$ evolution and mineral $\mathrm{N}$ released amongst residue particles size were smaller. We found that the amount ofC-CO $\mathrm{CO}_{2}$ and mineral-N released after 60 and 90 days of incubation were comparable with the figures found by Vanlauwe (1996) for agroforestry residues decomposing $\left(25^{\circ} \mathrm{C}\right)$ in a sandy soil after 28 days. But contrary to what they found, the smallest particles $(<$ $0.5 \mathrm{~mm}$ ) in our study, evolved more C- $\mathrm{CO}_{2}$ than coarse particles $(2-4 \mathrm{~mm})$ during the initial stage of decomposition. This also coincided with the lowest $\mathrm{C}$-to-N ratio and poorest fibre content of these fractions. However, our results were consistent with 
those of others (Waksman, 1952; Russell, 1961; Van Schreven, 1964) in the sense that fine residues had more $\mathrm{C}-\mathrm{CO}_{2}$ evolution in soil than large materials because finely divided residues have higher specific surface area than coarse particles. Jensen (1994), following earlier ideas from Strickler and Frederick (1959) and Sims and Frederick (1970), showed opposite results and postulated that clay minerals may exert a blocking effect on decomposition. Microbial biomass and its products formed during the initial stage of decomposition, would be better protected from further biodegradation from small particles, because of intimate mixing of residues with the soil. Soil protective effect has not been demonstrated here. Although the net of $\mathrm{N}$-mineralization rates showed significant differences at the beginning of decomposition before 10 days of incubation, any effect of soil texture may have also been observed for $\mathrm{C}$ mineralization. After 10 days, Wapril soil (loamy soil) had a significantly higher netinmobilization than Hualañé soil (sandy soil). This coincided with the tendency to find a higher rate of $\mathrm{C}$-mineralisation throughout the all incubation. This was consistent with Vanlauwe's results in which coarse residues showed a net $\mathrm{N}$ inmobilization with the highest C- $\mathrm{CO}_{2}$ evolution. However in Jensen's (1994) report, coarse materials had a net $\mathrm{N}$ mineralisation with the highest $\mathrm{C}-\mathrm{CO}_{2}$ producction. We speculate that the residue quality might have masked the protective effect of soil texture on residue decomposition of small particles, especially at the initial stage of decomposition when the protective effect occurs. The results of our study confirm the importance of standardising residue particle size and residue quality determination to relate their intrinsic chemical characteristics with their rate of $\mathrm{C}$ - and $\mathrm{N}$-mineralisation. Research needed to be focused on these topics, especially to establish the interaction between soil texture and $\mathrm{C}$ - and $\mathrm{N}$ mineralisation for fruit tree species, particularly when large pieces residues are left on soil.

\section{ACKNOWLEDGEMENTS}

We are grateful to Laboratorio de Suelos and Centro de Pomáceas, of the Universidad de Talca, for their financial support. 


\section{REFERENCES}

DALAL, R.C., 1979. Simple procedure for the determination of total carbon and its radioactivity in soils and plant materials. Analyst, 101:151-154.

JENSEN, E.S., 1994. Mineralizationimmobilization of nitrogen in soil amended with low $\mathrm{N}$ ratio plant residues with different particle sizes. Soil Biology and Biochemistry 26, 519-521.

KACHAKA, S., VANLAUWE, B. AND MERCKX, R., 1993. Decomposition and nitrogen mineralization of prunings of different quality. In: K. Mulongoy and R. Merckx (Editors), Soil Organic Matter Dynamics and Sustainability of Tropical Agriculture. John Wiley, Chichester, UK, pp. 199-208.

MATUS, F.J. (1994) Crop residue decomposition, residual soil organic matter and nitrogen mineralization in arable soils with contrasting textures. Doctoral Thesis, University of Wageningen, $141 \mathrm{p}$.

NELSON, D.W. AND SOMMERS, L.E., 1982. Total organic carbon and organic matter. In: A.L., Page, R.H., Miller y D.R. Keeney (Editors), Methods of soil analysis, Part 2, American Society of Agronomy, Madison, pp. 539-579.

OGLESBY, K. AND FOWNES, J.H., 1992. Effects of chemical composition on nitrogen mineralization from green manures of seven tropical leguminous trees. Plant and Soil, 143: 127-132.

PALM C. AND SÁNCHEZ, P.A., 1991. Nitrogen release from the leaves of some tropical legumes as affected by their lignin and polyphenolic contents. Soil Biology and Biochemistry, 23: 83-88.

RUSSELL, E. W., 1961. Soil conditions and plant growth. Longmans, Green and Co., London.
STRICKLER, F.C. AND FREDERICK, L.R., 1959. Residue particle size as a factor in nitrate release from legume tops and roots. Agronomy Journal, 51: 271-274.

SIMS, J.L. AND FREDERICK, L.R. 1970. Nitrogen immobilization and decomposition of green residue in soil and sand affected by residue particle size. Soil Science 109: 355-361.

TIAN, G., KANG, B. T. AND BRUSSAARD, L., 1992. Effects of chemical composition on $\mathrm{N}, \mathrm{Ca}$ and $\mathrm{Mg}$ release during incubation of leaves from selected agroforestry and fallow plant species. Biogeochemistry, 16: 103-119.

VANLAUWE, B., 1996. Residue quality, decomposition and soil organic matter dynamics under sub-humid tropical conditions. Ph.D. Thesis, Leuven Catholic University, Belgium.

VAN SCHREVEN, D.A., 1964. A comparison between the effect of fresh and dried organic materials added to soil on carbon and nitrogen mineralization. Plant and Soil, 2: 149-165.

VAN SOEST, P.J., 1963. Use of detergents in the analysis of fibrous feeds. II A rapid method for the determination of fiber and lignin. Journal of the Association of Official Analytical Chemists, 46: 829-835.

VAN SOEST, P.J. AND WINE, R.H., 1967. Use of detergents in the analysis of fibrous feeds IV. Determination of plant cell-wall constituents. Journal of the Association of Official Analytical Chemists, 50: 50-55.

VAN SOEST, P.J. AND WINE, R.H., 1968. Determination of lignin and cellulose in aciddetergent fiber with permanganate. Journal of the Association of Official Analytical Chemists 51: 780-785.

WAKSMAN, S.A., 1952. Soil microbiology. John Wiley and Sons, Inc. New York. $356 \mathrm{pp}$. 